\title{
鋼構造骨組の最小重量設計問題における凸緩和 A CONVEX RELAXATION FORMULATION FOR MINIMUM WEIGHT DESIGN PROBLEM OF STEEL FRAME STRUCTURES
}

\author{
宋 昶*, 山川誠**, 上谷宏二*** \\ Chang SONG, Makoto YAMAKAWA and Koji UETANI
}

\begin{abstract}
A convex relaxation formulation for a minimum weight design problem of steel frame structures is proposed in this paper. The non-convexity of this kind of problem usually results in only local optimal solutions. Further, although the global optimal solution is not always necessary, a better local optimal solution is always preferred. To measure the accuracy of a local optimal solution, we use branch and bound approach with reformulation-linearization technique. We propose a new region partitioning technique for this approach. The effectiveness of the formulation is investigated with two numerical examples.
\end{abstract}

Keywords: Steel frame structure, Minimum weight design, Reformulation-Linearization Techniques, Branch and bound approach 鋼構造骨組，最小重量設計，RLT線形緩和，分枝限定法

\section{1 はじめに}

構造設計者は構造物をモデル化した上で適当な設計を仮定し、応 答解析を行う。得られた応答值が設計条件を満足していなければ、 設計を変更し再び応答解析を行う必要がある。論理的な手法を適切 な部分に導入すれば、構造設計のサイクルにおける創造的な部分に 設計者は専念できるようになると考えられる。このような設計の論 理化において最適化の手法が有効であり、機械、航空機、自動車な どの分野では最適設計として製品の開発プロセスの一部に取り入れ られ、コス卜低減や安全性向上などに結びついている1,2)。建築構 造の分野でも、鋼材量最小化問題として鋼構造骨組の部材断面を設 計変数として許容応力度および層間変形角に関する条件を満たし最 小の鋼材量となるような設計解を求めるための研究が行われている。 このような最適化問題において、断面分布のパターンが大きく異な る設計解、即ち局所解が多数存在することが知られており3)、問題 の初期断面と局所解の関連性についての検討も行われている4)。こ の上うな初期值依存性は、問題の非凸性に起因寸ると考えられる。

\section{1 問題の性質と研究の背景}

凸計画問題とは目的関数が凸関数、実行可能領域が凸集合である ような問題である5)。ここで、集合 $\mathcal{S} \subset \mathbb{R}^{n}$ が凸集合であるとは、

$$
\forall \boldsymbol{x}, \boldsymbol{y} \in \mathcal{S} \Rightarrow \alpha \boldsymbol{x}+(1-\alpha) \boldsymbol{y} \in \mathcal{S} \quad \forall \alpha \in[0,1]
$$

が成り立つことをいう。また、関数 $f: \mathbb{R}^{n} \rightarrow \mathbb{R}$ が凸であるとは $f$ の epigraphが凸、すなわち

$$
f(\alpha \boldsymbol{x}+(1-\alpha) \boldsymbol{y}) \leq \alpha f(\boldsymbol{x})+(1-\alpha) f(\boldsymbol{y}) \quad \forall \boldsymbol{x}, \boldsymbol{y} \in \mathbb{R}^{n}, \forall \alpha \in[0,1]
$$
が成り立つことをいう。これらの関係を図1に示す。

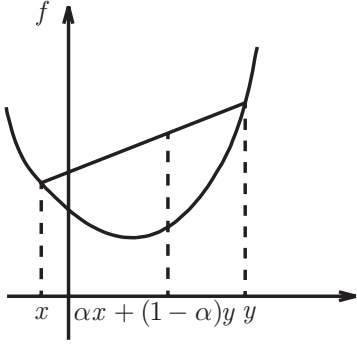

凸関数

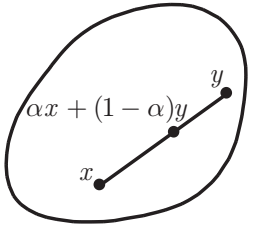

凸集合
図1 凸関数と凸集合

凸計画問題では任意の局所的最適解は大域的最適解である。一方、 非凸計画問題では局所的最適解が大域的最適解である保証はなく、 大域的最適解から大きく劣った局所的最適解が多数存在する可能性 がある5)。鋼構造建築物の鋼材量最小化問題においても非凸制約条 件が多数存在する。1 次設計における許容応力度制約、層間変形制 約、2 次設計における必要保有水平耐力制約は寸べて非凸制約条件 に分類される。このような非凸制約条件の存在により、局所的な最 適性条件を満た寸設計解は多数存在し、それらの中から大域的最適
* 京都大学大学院工学研究科建築学専攻 大学院生・修士 (工学)

** 京都大学工学研究科 助教・博士 (工学)

*** 京都大学工学研究科 教授. 工博
Graduate Student, Dept. of Architecture and Architectural Eng., Kyoto University, M. Eng.

Research Assoc., Dept. of Architecture and Architectural Eng., Kyoto University, Dr. Eng. Prof., Dept. of Architecture and Architectural Eng., Kyoto University, Dr. Eng. 
解を選ぶことは極めて困難である。大域的最適解という意味では、 部材断面を離散変数として定式化し列挙法を用いて求める方法が提 案されている6)。ただし、離散最適化問題も同様に解くことが難し い問題である。このような困難が存在する一方で、大域的最適解自 体への実用的な必要性は小さく、許容解が得られれば十分であると も考えられる。ただし、複数の局所解の目的関数值がそれほど変わ らなければどの局所解でも良いのであり、他の局所解よりも大きく 劣った解であれば、それはできる限り排除すべきである。以上より、 実用的な意味においても、局所解と厳密解との目的関数值の乘離度 を測り局所解の良さを評価することには意義があると考える。

\section{2 研究の位置づけ}

局所解（上界）の良さを測るために、緩和問題の最適解（下界） を利用することが可能である。元問題の非凸性を何らかの方法で除 去し、凸計画問題に緩和した問題を構成できれば、局所最適性によ り問題の下界を特徵づけることができる。このような大域的最適化 アルゴリズムの研究は1960年代には始まっている。近年になり、高 速かつ大容量の計算環境が提供されるようになったため、実用上の 応用についてより多くの研究が行われるようになっている6)。

目的関数および制約条件が変数の多項式で書かれた最適化問題は 多項式計画問題と呼ばれる。多項式計画問題は非凸二次計画問題の 一般化であるとともに、新しい変数を導入することにより多項式計 画問題を非凸二次計画問題として再定式化することも可能である7)。 このような定式化に対する凸緩和として線形緩和8)、二次錐緩和9)、 半正定值緩和10-12)等の方法が知られている。これらの中では半正定 值緩和が理論的には最も優れている。一方で、大規模な問題を数値 的に安定かつ高速に解くことができる線形計画ソルバーに基づく線 形緩和の利点も指摘されている13, 14)。実際に近年の線形計画ソルバ 一は設計変数および制約条件をそれぞれ 1 千万以上有する問題を数 時間で解くことができる15)。このような背景の下、線形緩和法の一 つであるReformulation-Linearization Techniques（RLT）と分枝 切除法とを組み合わせた方法8,16)の有効性が報告されている。

第2 章で示すように鋼構造骨組の鋼材量最小化問題も多項式計画 問題として定式化できる。このような点から鋼材量最小化問題を考 察することは実用的にも理論的にも興味深いものと思われるが、十 分な既往の研究はなされていないようである。

\section{3 研究の目的と論文の構成}

本論文では、弾性解析に基づく許容応力度設計についての設計条 件を単純化して考慮した上で、鋼構造平面骨組の鋼材量最小化問題 を多項式計画問題として定式化し、問題の性質を調べる。このよう な立場から以下について論じる。

1）鋼構造平面骨組の鋼材量最小化問題について、多項式計画問題 としての定式化を行った上で緩和問題を導出する。

2）領域分割に基づく分枝切除法により緩和問題の精度を向上する 方法を提案する。

3）緩和解を用いて局所解の信頼性をどの程度定量的に評価するこ とが可能かについて、数值解析例を通じて調べる。

第2章では本論文で対象とする設計問題の定式化を紹介し、RLT及 び分枝限定法を説明する。次に第3章では3層 3 スパンモデルと 7 層 3 スパンモデルの解析例を用いて提案手法の有効性を検証し、上界と 下界により局所解の信頼性について定量的な評価を行い、得られた
結論を第4章にまとめる。

\section{4 表記について}

非負整数全体の集合を $\mathbb{N}_{0}$ 、実数を成分とする $n$ 次元ベクトル全 体の集合を $\mathbb{R}^{n}$ と表す。二つのベクトル $\boldsymbol{x}, \boldsymbol{y} \in \mathbb{R}^{n}$ に対し、各成分を $x_{1}, \cdots, x_{n}, y_{1}, \cdots, y_{n}$ と表せば $x_{i} \leq y_{i} ; i=1, \cdots, n$ であるとき $\boldsymbol{x} \leq \boldsymbol{y}$ と書 く。零ベクトルは $\mathbf{0}$ と表す。(.)および(.)によって、対応する変数の 上下限值を表す。集合 $\mathcal{S}$ に対し、 $|\mathcal{S}|$ は $\mathcal{S}$ の要素数（または濃度） を表す。最小化問題を対象として、単に「最適解」と言った場合に は大域的な最小解を指し、そうでない局所的な最小解を指寸場合に は局所解と呼ぶ。ある問題の最適解に対応する目的関数值を最適值 と呼び、解が存在しない問題に対する最適值は $+\infty$ とする。

\section{2 設計問題の定式化}

前章で述べたように鋼構造建築物の鋼材量最小化問題は局所解が 多数存在する非凸計画問題である。まず2.1節で単純モデルを通じ て問題の性質を把握することを試み、緩和問題の意義を説明した上 で、2.2節で多項式計画問題としての一般的な定式化を与える。 2.3 節ではRLTおよび妥当不等式を用いた線形緩和問題について述べ

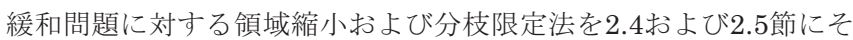
れぞれ説明する。

\section{1 単純モデル（剛棒連結モデル）}

単純モデルとして、図2に示すような二本の鉛直柱が水平な剛棒 $R$ に連結されている剛棒連結モデルを考える。二本の鉛直柱はそれ ぞれ断面積 $A_{1}, A_{2}$ および断面二次モーメント $I_{1}, I_{2}$ を有するとし、 柱の長さを $h 、$ ヤング係数を $E$ とする。

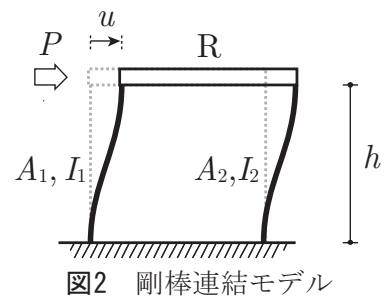

外力 $P$ に対して生じる変位を $u$ とすると、系剛性方程式は

$$
P=\left(12 E I_{1} / h^{3}+12 E I_{2} / h^{3}\right) u
$$

と表せる。さらにそれぞれの柱の断面積、断面二次モーメント関係 はパラメータ $\alpha$ を用いて

$$
I_{1}=\alpha A_{1}^{2}, I_{2}=\alpha A_{2}^{2}
$$

と与える。各柱の断面積の上下限值制約 $A_{1} \leq A_{1} \leq \bar{A}_{1}, \underline{A}_{2} \leq A_{2} \leq \bar{A}_{2}$ および変位制約 $0 \leq u \leq \bar{u}$ を与えたで、鋼材量 $h A_{1}+h A_{2}$ を最小化 するような $A_{1}, A_{2}, u$ を見出す問題

$$
\begin{array}{ll}
\min _{A_{1}, A_{2}, u} & h A_{1}+h A_{2}, \\
\text { s.t. } & P=\left(\frac{12 E}{h^{3}} I_{1}+\frac{12 E}{h^{3}} I_{2}\right) u=\frac{12 E \alpha}{h^{3}}\left(A_{1}^{2} u+A_{2}{ }^{2} u\right), \\
& \underline{A}_{1} \leq A_{1} \leq \bar{A}_{1}, \quad \underline{A}_{2} \leq A_{2} \leq \bar{A}_{2}, \quad 0 \leq u \leq \bar{u} .
\end{array}
$$

を考える。簡単のために $h=1,12 E \alpha / h^{3}=1, P=1, \bar{u}=1$ と与え、 $u$ について縮約するとこの問題は

$$
\begin{aligned}
& \min _{A_{1}, A_{2}} \quad A_{1}+A_{2}, \\
& \left(\mathrm{PE}_{0}\right) \text { : } \quad \text { s.t. } \quad A_{1}^{2}+A_{2}^{2} \geq 1 \text {, } \\
& \underline{A}_{1} \leq A_{1} \leq \bar{A}_{1}, \quad \underline{A}_{2} \leq A_{2} \leq \bar{A}_{2} \text {. }
\end{aligned}
$$


と書き換えることができる。ここで、 $(0<) \underline{A}_{1}<\underline{A}_{2}(<1)$ および $(1<) \bar{A}_{1}=\bar{A}_{2}=\bar{A}$ とする。問題 $\left(\mathrm{PE}_{0}\right)$ は非凸二次計画問題であり、 その非凸性は制約条件 $A_{1}^{2}+A_{2}{ }^{2} \geq 1$ に由来寸るものである。問題 $\left(\mathrm{PE}_{0}\right)$ の許容領域および目的関数の等高線を白抜きの領域および灰 色の線としてそれぞれ描いた図を図3に示寸。問題 $\left(\mathrm{PE}_{0}\right)$ には二つの 局所解

$$
\begin{aligned}
& \text { 局所解 } 1:\left(A_{1}, A_{2}\right)=\left(\underline{A}_{1}, \sqrt{1-\underline{A}_{1}^{2}}\right) \\
& \text { 局所解2: }\left(A_{1}, A_{2}\right)=\left(\sqrt{1-\underline{A}_{2}^{2}}, \underline{A}_{2}\right)
\end{aligned}
$$

が存在し、あわせて図3に黒点で示す。図3の目的関数の等高線から もわかるように局所解1が最適解である。しかし、局所的な勾配情 報に基づく非線形最適化法を適用した場合に、局所解 1,2 のいずれが 解として得られるかは初期值や実装方法に依存寸る。これが鋼材量 最小化問題において初期值依存性として知られる現象である。

問題 $\left(\mathrm{PE}_{0}\right)$ において、独立変数 $y_{1}^{(1)}, y_{1}^{(2)}, y_{2}^{(1)}, y_{2}^{(2)}$ を新たに導入して変 数の置き換え

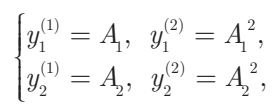

を考える。問題 $\left(\mathrm{PE}_{0}\right)$ における線形不等式を掛け合わせて作られる ような不等式は妥当不等式と呼ばれ、(5)のような関係を用いて条件 式を書き換えることは線形化と呼ばれる。第 $i$ 部材についての線形 不等式 $A_{i} \leq A_{i}, A_{i} \leq \bar{A}_{i}$ から作られる妥当不等式およびその線形化 を次に示す。

$$
\left\{\begin{array}{l}
\left(\underline{A}_{i}-A_{i}\right)^{2} \geq 0 \\
\left(\underline{A}_{i}-A_{i}\right)\left(A_{i}-\bar{A}_{i}\right) \geq 0 \Rightarrow\left\{\begin{array}{l}
y_{i}^{(2)}-2 \underline{A}_{i} y_{i}^{(1)}+\underline{A}_{i}^{2} \geq 0 \\
-y_{i}^{(2)}+\left(\underline{A}_{i}+\bar{A}_{i}\right) y_{i}^{(1)}-\underline{A}_{i} \bar{A}_{i} \geq 0 \\
\left(A_{i}-\bar{A}_{i}\right)^{2} \geq 0
\end{array} y_{i}^{(2)}-2 \bar{A}_{i} y_{i}^{(1)}+\bar{A}_{i}^{2} \geq 0\right.
\end{array}\right.
$$

問題 $\left(\mathrm{PE}_{0}\right)$ において妥当不等式は明らかに圥長な制約条件であり、 問題 $\left(\mathrm{PE}_{0}\right)$ の許容領域に何ら影響を与えない。(5)に対応する等式制 約 $y_{i}^{(2)}=\left(y_{i}^{(1)}\right)^{2}$ を黒線で、(6)の線形化された妥当不等式により作られ る集合を白抜きの領域で描いた図を図4に示す。(5)の本質は二次等 式制約であり、これは非凸制約である。一方、線形化された妥当不 等式により作られる集合は凸集合であり、 $\underline{A}_{i} \leq A_{i} \leq \bar{A}_{i}$ において非 凸制約(5)を含む。つまり、線形化された妥当不等式(6)は非凸制約(5) の凸緩和である。以上のような考えから問題(4)の凸緩和問題

$$
\begin{aligned}
\min _{y_{1}^{(1)}, y_{2}^{(1)}, y_{1}^{(2)}, y_{2}^{(2)}} & y_{1}^{(1)}+y_{2}^{(1)}, \\
\text { s.t. } \quad & y_{1}^{(2)}+y_{2}^{(2)} \geq 1, \\
\left(\mathrm{PE}_{\mathrm{L}}{ }^{\prime \prime}\right): \quad & \underline{A}_{i} \leq y_{i}^{(1)} \leq \bar{A}_{i}, \\
& 2 \underline{A}_{i} y_{i}^{(1)}-y_{i}^{(2)} \leq \underline{A}_{i}{ }^{2}, \\
& -\left(\underline{A}_{i}+\bar{A}_{i}\right) y_{i}^{(1)}+y_{i}^{(2)} \leq-\underline{A}_{i} \bar{A}_{i}, \\
& 2 \bar{A}_{i} y_{i}^{(1)}-y_{i}^{(2)} \leq \bar{A}_{i}{ }^{2}, \quad(i=1,2) .
\end{aligned}
$$

が導かれる。問題 $\left(\mathrm{PE}_{\mathrm{L}}{ }^{\prime \prime}\right)$ は線形制約のみからなるので線形計画問題 である。問題 $\left(\mathrm{PE}_{\mathrm{L}}{ }^{\prime \prime}\right)$ に非線形制約条件 $(5)$ を加えれば元問題 $\left(\mathrm{PE}_{0}\right)$ と 等価な問題となるので、問題 $\left(\mathrm{PE}_{0}\right)$ から非凸制約(5)を取り除いた問 題 $\left(\mathrm{PE}_{\mathrm{L}}{ }^{\prime \prime}\right)$ は問題 $\left(\mathrm{PE}_{0}\right)$ の緩和問題であることは明らかである。この ような線形緩和を用いる方法がRLTである。問題 $\left(\mathrm{PE}_{\mathrm{L}}{ }^{\prime \prime}\right)$ における許 容領域および最適解（緩和解1）の例を白抜きの領域および白点と してそれぞれ図5に示す。図5から分かるように、緩和問題 $\left(\mathrm{PE}_{\mathrm{L}}{ }^{\prime \prime}\right)$ の 許容領域は元問題 $\left(\mathrm{PE}_{0}\right)$ すなわち図 3 の許容領域を含む凸領域であ る。

対象となる領域を分割すれば緩和解の精度を高めることができる。
例えば、 $A_{1} \leq A_{1}^{C} \leq \bar{A}$ となるような $A_{1}^{C}$ を用いて上下限制約を $\underline{A}_{1} \leq A_{1} \leq A_{1}^{C}$ および $A_{1}^{C} \leq A_{1} \leq \bar{A}$ に分割し、対応する二つの緩和問 題をそれぞれ解くことにより緩和解の精度を向上させることができ る。領域分割された緩和問題の許容領域および最適解（緩和解2） の例を白抜きの領域および白点としてそれぞれ図6に示す。

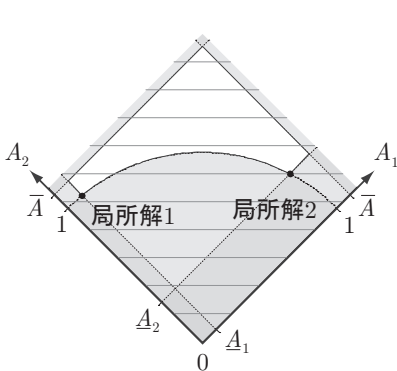

図3剛棒連結モデルの 許容領域と局所解

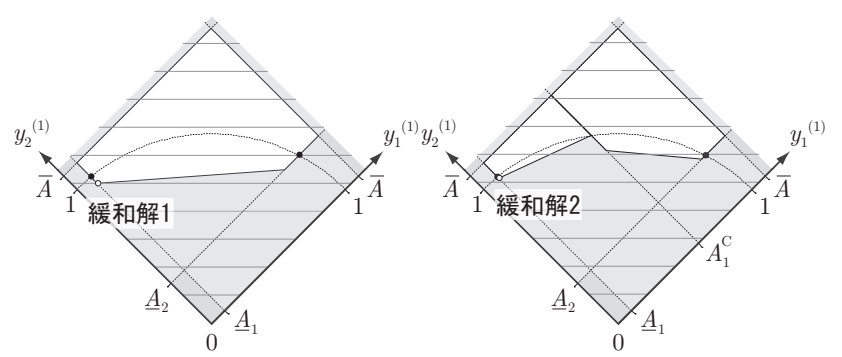

図5
例として $A_{1}=0.1, A_{1}^{C}=0.6, \bar{A}=1.1, \underline{A}_{2}=0.3$ と与えた場合の、 上記各ケースの目的関数值および大域的最適解（局所解1）からの 目的関数值の乘離の割合を表 1 に示す。

表1 単純モデルにおける最適解の目的関数值

\begin{tabular}{c|cccc}
\hline & $\begin{array}{c}\text { 局所解1 } \\
\text { (上界) }\end{array}$ & $\begin{array}{c}\text { 局所解 } \\
\text { (上界) }\end{array}$ & $\begin{array}{c}\text { 緩和解1 } \\
\text { (下界) }\end{array}$ & $\begin{array}{c}\text { 緩和解 } 2 \\
\text { (下界) }\end{array}$ \\
\hline \hline 目的関数值 & 1.095 & 1.254 & 1.043 & 1.084 \\
乘離度 & - & $+14.51 \%$ & $-4.76 \%$ & $-0.99 \%$ \\
\hline
\end{tabular}

緩和問題の最適解を用いて、元問題の局所解の良さを測ることに ついて簡単に説明する。まず、元問題の任意の許容解は緩和問題で も許容解である。よって、元問題のどの許容解の目的関数值よりも 緩和問題の最適值は小さい。例えば図 3 の許容領域と図 5 の緩和解 1 を比較すれば、この関係は容易に理解される。よって、緩和問題の 最適值は元問題の最適値の下界である。次に、定義から元問題の任 意の許容解の目的関数值は元問題の最適值よりも大きい。例えば、 図3において最適解（局所解1）は他のどの許容解よりも小さな目的 関数值をとっている。よって、元問題の任意の許容解の目的関数値 は元問題の最適值の上界である。元問題の最適值はこのような上界 と下界の間に存在する。ある局所解の目的関数值を上界とすれば、 下界（緩和問題の最適値）との差を測ることにより、その局所解の 
良さを評価することができる。上界と下界が一致した場合には、そ の局所解は真の最適解である。表 1 において、緩和解 2 のうう精度 の高い目的関数值の下界が得られていれば、局所解 1 は大域的最適 解からの乘離度は高々 $1 \%$ 以下過ぎないことがわかり、一方で局所 解 2 にいては他に大域的最適解が存在する可能性が高いことがわ かる。より一般的な定式化を次節以降に述べる。

\section{2 多項式計画問題としての鋼材量最小化問題の定式化（元問題）}

まず、鋼構造平面骨組鋼材量最小化問題の定式化を示す。 $n_{X}, n_{U}$ を それぞれ部材断面数、系全体の自由度数として、設計変数を $x \in \mathbb{R}^{n_{X}}$ および $\boldsymbol{u} \in \mathbb{R}^{n_{U}}$ とする。これらの第 $i$ 成分を $x_{i}$ および $u_{i}$ と書く。第 $i$ 部材断面に関係する設計変数 $x_{i}$ と断面積 $A_{i}$ 、形状係数 $Z_{i}$ 、断面二 次モーメント $I_{i}$ との関係を

$$
A_{i}=A_{i}\left(x_{i}\right)=\alpha_{i} x_{i}^{2}, Z_{i}=Z_{i}\left(x_{i}\right)=\beta_{i} x_{i}^{3}, I_{i}=I_{i}\left(x_{i}\right)=\gamma_{i} x_{i}^{4},
$$

と与える。 $\alpha_{i}, \beta_{i}, \gamma_{i}$ はそれぞれ部材の形状によって定められる定数 である。柱部材には角形鋼管、梁部材にはH形鋼を用い、 $i \in \mathcal{I}^{C}$ は 柱断面に関係する部材断面番号、 $i \in \mathcal{I}^{G}$ は梁断面に関係する部材断 面番号を表すとして、

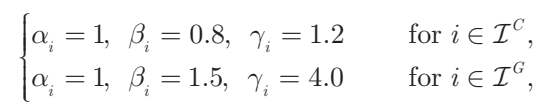

と与える。目的関数を鋼材量とし、

$$
f(\boldsymbol{x})=\sum_{j=1}^{n_{M}} \sum_{i=1}^{n_{X}} L_{j} C_{i j} A_{i}
$$

と定義する。ここで、 $n_{M}$ は総部材数、 $C_{i j} ; i=1, \cdots, n_{X}, j=1, \cdots, n_{M}$ は 第 $i$ 部材断面に関する量から対応する第 $j$ 部材に関する量に変換す るための0-1係数、 $L_{j} ; j=1, \cdots, n_{M}$ は第 $j$ 部材の部材長を表す。以降 では表記を簡潔にするために誤解のない限り第 $j$ 部材に関する断面 積も同じ記号で $A_{j}$ と表す。本来は、第 $i$ 部材断面に関する量と第 $j$ 部材に関する量は区別すべきであり、第 $j$ 部材に関する断面積は正 確には $\sum_{i=1}^{n_{X}} C_{i j} A_{i}$ と表すべきことに注意されたい。このような表記を 用いれば、(10)は簡潔に

$$
f(\boldsymbol{x})=\sum_{j=1}^{n_{M}} L_{j} A_{j}
$$

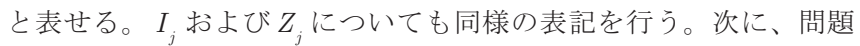
の単純化のために以下の仮定をおく。

[仮定1］剛床仮定を行う。

[仮定2］柱の伸び変形を考慮しない。

そのため、各層の水平変位は等しく、また鉛直変位は考えない。こ のとき、第 $j$ 部材の材端力一材端変位関係式を

$$
\boldsymbol{p}_{j}=\boldsymbol{Q}_{j} I_{j} \boldsymbol{u}_{j}
$$

と表す。ここで、 $\boldsymbol{p}_{j}=\left(p_{j}^{(a)}, m_{j}^{(a)}, p_{j}^{(b)}, m_{j}^{(b)}\right) \in \mathbb{R}^{4}$ は第 $j$ 部材の（基準 座標系) 材端力ベクトル、 $\boldsymbol{u}_{j}=\left(u_{j}^{(a)}, \theta_{j}^{(a)}, u_{j}^{(b)}, \theta_{j}^{(b)}\right)^{T} \in \mathbb{R}^{4}$ は第 $j$ 部材の (基準座標系) 材端変位ベクトル、 $\boldsymbol{Q}_{j} \in \mathbb{R}^{4 \times 4}$ はヤング係数 $E$ およ び部材長 $L_{j}$ を用いて表される行列として

$$
E\left(\begin{array}{cccc}
12 \sin ^{2} \varphi_{j} / L_{j}^{3} & -6 \sin \varphi_{j} / L_{j}^{2} & -12 \sin ^{2} \varphi_{j} / L_{j}^{3} & -6 \sin \varphi_{j} / L_{j}^{2} \\
& 4 / L_{j} & 6 \sin \varphi_{j} / L_{j}^{2} & 2 / L_{j} \\
& & 12 \sin ^{2} \varphi_{j} / L_{j}^{3} & 6 \sin \varphi_{j} / L_{j}^{2} \\
\operatorname{sym} . & & & 4 / L_{j}
\end{array}\right)
$$

と与える。ここで、 $\varphi_{j}$ は材軸が（基準座標系）水平方向軸に対して な寸角であり、第 $j$ 部材端 $a, b$ の鉛直上向き方向の座標值 $\eta_{j}^{(a)}, \eta_{j}^{(b)}$
を用いて $\sin \varphi_{i}=\left(\eta_{j}^{(b)}-\eta_{j}^{(a)}\right) / L_{j}$ とする。(12)を系全体で重ね合わせ、 系剛性方程式

$$
K(x) u=P
$$

が得られる。ここで、 $\boldsymbol{K}(\boldsymbol{x}) \in \mathbb{R}^{n_{U} \times n_{U}}$ は系全体の剛性行列、 $\boldsymbol{P} \in \mathbb{R}^{n_{U}}$ はある作用荷重に対する等価節点力ベクトルとする。層数を $n_{S}$ とし、

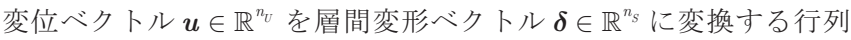
$\boldsymbol{R} \in \mathbb{R}^{n_{S} \times n_{V}}$ 、および許容最大層間変形 $\overline{\boldsymbol{\delta}} \in \mathbb{R}^{n_{S}}$ を用いて、ある荷重 作用時の層間変形制約を

$$
R u \leq \bar{\delta}
$$

と表す。また、ある荷重作用時の第 $j$ 部材に関する部材端曲げ許容 応力度（短期）を満たすための条件式を

$$
\begin{aligned}
& -1.5 f_{b} Z_{j} \leq m_{j}^{(a)}+q_{j}^{(a)} \leq 1.5 f_{b} Z_{j}, \\
& -1.5 f_{b} Z_{j} \leq m_{j}^{(b)}+q_{j}^{(b)} \leq 1.5 f_{b} Z_{j} ; j=1, \cdots n_{M}
\end{aligned}
$$

と与える。ここで、 $m_{j}^{(a)}, m_{j}^{(b)}$ は第 $j$ 部材の材端力ベクトル $\boldsymbol{p}_{j} \in \mathbb{R}^{4}$ の 第 2,4 成分であり、 $q_{j}^{(a)}, q_{j}^{(b)}$ はある作用荷重に対する固定端モーメン 卜とする。(15)をまとめて $s(\boldsymbol{x}, \boldsymbol{u}) \leq \mathbf{0}$ と表す。さらに目的関数值（鋼 材量）が適当に与えられた上界以下という条件

$$
f(\boldsymbol{x}) \leq \bar{f}
$$

を与える。以上を用いて多項式計画問題としての鋼材量最小化問題 $\min _{x, u} f(\boldsymbol{x})$

$\begin{array}{rll}\text { s.t. } & \boldsymbol{K}(\boldsymbol{x}) \boldsymbol{u}=\boldsymbol{P}, & \text { (剛性方程式) } \\ \left(P_{0}\right): & \boldsymbol{R} \boldsymbol{u} \leq \overline{\boldsymbol{\delta}}, & \text { (層間変形角制約) } \\ & s(\boldsymbol{x}, \boldsymbol{u}) \leq \mathbf{0}, & \text { (許容応力度制約) } \\ & f(\boldsymbol{x}) \leq \bar{f}, & \text { (鋼材量制約) } \\ & \underline{x} \leq \boldsymbol{x} \leq \overline{\boldsymbol{x}}, \underline{\boldsymbol{u}} \leq \boldsymbol{u} \leq \overline{\boldsymbol{u}}, & (\text { 上下限制約) }\end{array}$

を定義する。ここで、次の仮定をおく。

[仮定3] $\underline{u}, \bar{u}$ は対応寸る成分について同符号かつ0ではない。 すなわち、 $j=1,2, \cdots, n_{U}$ に対して $0<\underline{u}_{j} \leq \bar{u}_{j}$ あるいは $\underline{u}_{j} \leq \bar{u}_{j}<0$ のいずれかが成り立つ。ここで、 $\underline{u}_{j}, \bar{u}_{j}$ は $\underline{u}, \bar{u}$ の第 $j$ 成分とする。

問題 $P_{0}$ の目的関数、およびすべての制約関数（制約条件の左辺）は それぞれ設計変数 $x_{i}$ および $u_{j}$ についての多項式関数

$$
\sum_{i=1}^{n_{X}} \sum_{k=1}^{4} a_{i k}\left(x_{i}\right)^{k}+\sum_{(i, j) \in \mathcal{K}} \sum_{k=1}^{4} b_{i j k}\left(x_{i}\right)^{k} u_{j}+\sum_{j=1}^{n_{V^{j}}} c_{j} u_{j}+d
$$

と表せる。ここで、 $a_{i k}, b_{i j k}, c_{j}, d \in \mathbb{R}$ とする。よって、問題 $P_{0}$ は多項 式計画問題である。

\section{3 RLTを用いた線形緩和問題の定式化}

多項式(17)の線形化のために、新たな設計変数

$$
\begin{aligned}
& \boldsymbol{y}_{i}=\left(\begin{array}{llll}
y_{i}^{(1)} & y_{i}^{(2)} & y_{i}^{(3)} & y_{i}^{(4)}
\end{array}\right)^{T} \in \mathbb{R}^{4} ; i=1, \cdots, n_{X}, \\
& \boldsymbol{z}_{i, j}=\left(\begin{array}{llll}
z_{i, j}^{(1)} & z_{i, j}^{(2)} & z_{i, j}^{(3)} & z_{i, j}^{(4)}
\end{array}\right)^{T} \in \mathbb{R}^{4} ; i=1, \cdots, n_{X}, \quad j=1, \cdots, n_{U}
\end{aligned}
$$

を導入する。これらの変数に対して非凸制約

$y_{i}^{(1)}=x_{i}, y_{i}^{(2)}=\left(x_{i}\right)^{2}, y_{i}^{(3)}=\left(x_{i}\right)^{3}, \quad y_{i}^{(4)}=\left(x_{i}\right)^{4} ; i=1, \cdots, n_{X}$,

$z_{i, j}^{(1)}=x_{i} u_{j}, z_{i, j}^{(2)}=\left(x_{i}\right)^{2} u_{j}, z_{i, j}^{(3)}=\left(x_{i}\right)^{3} u_{j}, z_{i, j}^{(4)}=\left(x_{i}\right)^{4} u_{j} ;(i, j) \in \mathcal{K}$

を与える。ここで、 $\boldsymbol{z}_{i, j}$ について考慮する必要のある部材断面番号 $i$ と自由度番号 $j$ の組合せの寸べてを $\mathcal{K} \subset\left\{1,2, \cdots n_{X}\right\} \times\left\{1,2, \cdots n_{U}\right\}$ と 表す。さらに、第 $i$ 部材断面に関係する自由度番号 $j$ の集合を $\mathcal{K}(i) \subset\left\{1,2, \cdots n_{U}\right\}$ 、第 $j$ 自由度に関係する部材断面番号 $i$ の集合を $\mathcal{K}(j) \subset\left\{1,2, \cdots n_{X}\right\}$ と表す。 $\boldsymbol{y}_{i} ; i=1, \cdots, n_{X}$ および $\boldsymbol{z}_{i, j} ;(i, j) \in \mathcal{K}$ のそれ ぞれを列べクトルとして並べたものを $y$ および $\boldsymbol{z}$ と表し、変位べク 
トル $\boldsymbol{u}$ とあわせて線形化された問題の設計変数 $\boldsymbol{\xi}=\left(\boldsymbol{y}^{T}, \boldsymbol{u}^{T}, \boldsymbol{z}^{T}\right)^{T}$ と 定義する。 $\boldsymbol{\xi}$ の次元を $n$ とし、 $\xi_{k}$ と書いた場合には $\boldsymbol{\xi}$ の第 $k$ 成分を 表す。ここで、 $\xi_{k}$ は $y_{i}^{(l)}, u_{j}, z_{i, j}^{(l)}$ のいずれかに対応するものである。 以降では、非凸制約(19)を簡潔に

$$
\boldsymbol{\xi} \in \mathcal{N}
$$

と表す。

\subsection{1 元問題の線形化}

(20)の下で $\boldsymbol{\xi}$ を用いた問題 $P_{0}$ を考える。展開した多項式の非線形 項を対応する変数に置き換え線形関数化する操作を線形化と呼ぶ。 このような操作により線形化された多項式を $[\cdot]$, と表す。多項式制約 から作られる集合において、要素である各多項式を線形化すること により作られる集合も同じく $[\cdot]_{l}$ と表す。例えば、多項式 $x_{i}+\left(x_{i}\right)^{2}$ に 対して $\left[x_{i}+\left(x_{i}\right)^{2}\right]_{l}=y_{i}^{(1)}+y_{i}^{(2)}$ 、集合 $\mathcal{F}=\left\{x_{i} \mid 0 \leq x_{i}+\left(x_{i}\right)^{2} \leq 1\right\}$ に対 して $[\mathcal{F}]_{l}=\left\{\left(y_{i}^{(1)}, y_{i}^{(2)}\right) \mid 0 \leq y_{i}^{(1)}+y_{i}^{(2)} \leq 1\right\}$ とする。このとき、問題 $P_{0}$ を

$$
\left(P_{0}^{\prime}\right): \min _{\boldsymbol{\xi}}[f(\boldsymbol{x})]_{l}, \quad \text { s.t. } \boldsymbol{\xi} \in[\Omega]_{l}, \underline{\boldsymbol{\xi}} \leq \boldsymbol{\xi} \leq \overline{\boldsymbol{\xi}}, \boldsymbol{\xi} \in \mathcal{N}
$$

と書き換えることができる。ここで、

$$
\Omega=\{(\boldsymbol{x}, \boldsymbol{u}) \mid \boldsymbol{K}(\boldsymbol{x}) \boldsymbol{u}=\boldsymbol{P}, \quad \boldsymbol{R} u \leq \overline{\boldsymbol{\delta}}, \quad s(\boldsymbol{x}, \boldsymbol{u}) \leq \mathbf{0}, \quad f(\boldsymbol{x}) \leq \bar{f}\}
$$

とする。また、上下限値 $\underline{\boldsymbol{\xi}}=\left(\underline{\boldsymbol{y}}^{T}, \underline{\boldsymbol{u}}^{T}, \underline{\boldsymbol{z}}^{T}\right)^{T}, \overline{\boldsymbol{\xi}}=\left(\overline{\boldsymbol{y}}^{T}, \overline{\boldsymbol{u}}^{T}, \overline{\boldsymbol{z}}^{T}\right)^{T}$ につい ては余分な領域を取り去ることが望ましい。そのために $\underline{y}, \bar{y}, \underline{z}, \bar{z}$ の各成分を次式から計算する。

$$
\begin{aligned}
& \underline{y}_{i}^{(k)} \leftarrow\left(\underline{x}_{i}\right)^{k}, \bar{y}_{i}^{(k)} \leftarrow\left(\bar{x}_{i}\right)^{k} ; i=1, \cdots, n_{X}, k=1,2,3,4 \\
& \underline{z}_{i, j}^{(k)} \leftarrow \min \left\{\left(\underline{x}_{i}\right)^{k} \underline{u}_{j},\left(\bar{x}_{i}\right)^{k} \underline{u}_{j}\right\} ; \quad(i, j) \in \mathcal{K}, k=1,2,3,4 \\
& \bar{z}_{i, j}^{(k)} \leftarrow \max \left\{\left(\underline{x}_{i}\right)^{k} \bar{u}_{j},\left(\bar{x}_{i}\right)^{k} \bar{u}_{j}\right\} ; \quad(i, j) \in \mathcal{K}, k=1,2,3,4
\end{aligned}
$$

ここで、 $0<\underline{x}_{i} \leq \bar{x}_{i}$ および仮定3を考慮した。(21)について、 $\underline{\boldsymbol{x}}, \overline{\boldsymbol{x}}, \underline{\boldsymbol{u}}, \overline{\boldsymbol{u}}$

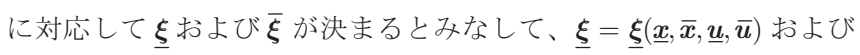
$\overline{\boldsymbol{\xi}}=\overline{\boldsymbol{\xi}}(\underline{\boldsymbol{x}}, \overline{\boldsymbol{x}}, \underline{\boldsymbol{u}}, \overline{\boldsymbol{u}})$ と表す。問題 $P_{0}$ と問題 $P_{0}^{\prime}$ は等価であり、これらの 問題の最適値は一致する。問題 $P_{0}^{\prime}$ の目的関数は線形関数であり、 $\boldsymbol{\xi} \in \mathcal{N}$ 以外の制約関数も寸べて線形関数である。よって、 $\boldsymbol{\xi} \in \mathcal{N}$ を 問題 $P_{0}^{\prime}$ から取り除けば、問題 $P_{0}^{\prime}$ の線形緩和問題

$$
\left(P_{L}^{\prime}\right): \min _{\xi}[f(\boldsymbol{x})]_{l}, \quad \text { s.t. } \boldsymbol{\xi} \in[\Omega]_{l}, \underline{\boldsymbol{\xi}} \leq \boldsymbol{\xi} \leq \overline{\boldsymbol{\xi}},
$$

が得られる。一般に、問題 $P_{L}^{\prime}$ の許容領域は問題 $P_{0}^{\prime}$ の許容領域より も大きく緩和される。より “強い” 緩和問題を作るために、次節で 述べる妥当不等式を導入する。ここで “強い” 緩和問題とは元問題 $P_{0}$ の最適值に近い最適値を持つ緩和問題を指す。

\subsection{2 妥当不等式を考慮した線形緩和問題}

妥当不等式とは、元問題に対して圥長な制約条件であり、一方、 緩和問題に対しては許容領域を制限することができる不等式制約で ある。RLTにおいて、線形化された妥当不等式は緩和の強さに大き な影響を与える重要な制約条件である。元問題におけるいくつかの 制約条件を掛け合わせることにより妥当不等式は作られる。 いての線形関数として表せる範囲内、寸なわち多項式関数(17)で表 せる範囲内で妥当不等式を考える。具体的には、元問題における上 下限制約と層間変形制約について、妥当不等式を作成する。まず、 元問題における設計変数の上下限制約 $\underline{x}_{i} \leq x_{i} \leq \bar{x}_{i} ; i=1, \cdots, n_{X}$ につ いての妥当不等式から作られる集合

$$
\begin{aligned}
V^{I}= & V^{I}(\underline{\boldsymbol{x}}, \overline{\boldsymbol{x}}) \\
= & \left\{\{\boldsymbol{x}, \boldsymbol{u}\} \mid\left(-x_{i}+\underline{x}_{i}\right)^{k}\left(x_{i}-\bar{x}_{i}\right)^{l}(-1)^{5-k-l} \leq 0 ;\right. \\
& \left.\quad i=1, \cdots, n_{X}, k \in \mathbb{N}_{0}, l \in \mathbb{N}_{0}, 2 \leq k+l \leq 4\right\}
\end{aligned}
$$

を定義する。次に、変位の上下限制約 $\underline{u}_{j} \leq u_{j} \leq \bar{u}_{j} ; j=1, \cdots, n_{U}$ を含 めて作られる妥当不等式の集合

$$
\begin{aligned}
V^{I I}=V^{I I}(\underline{\boldsymbol{x}}, \overline{\boldsymbol{x}}, \underline{u}, \overline{\boldsymbol{u}}) & \\
=\{\{\boldsymbol{x}, \boldsymbol{u}\} \mid & \left(-x_{i}+\underline{x}_{i}\right)^{k}\left(x_{i}-\bar{x}_{i}\right)^{l}\left(-u_{j}+\underline{u}_{j}\right)(-1)^{4-k-l} \leq 0 \\
& \left(-x_{i}+\underline{x}_{i}\right)^{k}\left(x_{i}-\bar{x}_{i}\right)^{l}\left(u_{j}-\bar{u}_{j}\right)(-1)^{4-k-l} \leq 0 ; \\
& \left.(i, j) \in \mathcal{K}, k \in \mathbb{N}_{0}, l \in \mathbb{N}_{0}, 1 \leq k+l \leq 4\right\}
\end{aligned}
$$

を定義する。層間変形角制約(14)における行列 $\boldsymbol{R}$ の第 $m$ 行 $j$ 列成分 $\left(1 \leq m \leq n_{S}, 1 \leq j \leq n_{U}\right)$ を $R_{m j} 、 \bar{\delta}$ の第 $m$ 成分を $\bar{\delta}_{m}$ とし、層間変形 角制約(14)を

$$
\sum_{j=1}^{n_{S}} R_{m j} u_{j} \leq \bar{\delta}_{m} ; m=1, \cdots, n_{S}
$$

と表す。このとき、(14)を含めて作られる妥当不等式の集合 $V^{I I I}=V^{I I I}(\boldsymbol{x}, \overline{\boldsymbol{x}})$

$$
\begin{gathered}
=\left\{\{\boldsymbol{x}, \boldsymbol{u}\} \mid\left(-x_{i}+\underline{x}_{i}\right)^{k}\left(x_{i}-\bar{x}_{i}\right)^{l}\left(\sum_{j=1}^{n_{V}}\left(R_{m j} u_{j}\right)-\bar{\delta}_{m}\right)(-1)^{4-k-l} \leq 0\right. \\
\left.(i, j) \in \mathcal{K}, m=1, \cdots, n_{S}, k \in \mathbb{N}_{0}, l \in \mathbb{N}_{0}, 1 \leq k+l \leq 4\right\}
\end{gathered}
$$

を定義する。(22),(23),(25)の $V^{I}, V^{I I}, V^{I I I}$ に含まれる条件式は(17)の 形で表される。よって、これらの妥当不等式は $\boldsymbol{\xi}$ こる線形化が可 能である。さらに $V^{I}, V^{I I}, V^{I I I}$ は問題 $P_{0}^{\prime}$ に対して圥長な制約条件で あるので、新たな問題

$\left(P_{0}^{\prime \prime}\right): \min _{\boldsymbol{\xi}}[f(\boldsymbol{x})]_{l}, \quad$ s.t. $\boldsymbol{\xi} \in[\Omega]_{l}, \underline{\boldsymbol{\xi}} \leq \boldsymbol{\xi} \leq \overline{\boldsymbol{\xi}}, \boldsymbol{\xi} \in[V]_{l}, \boldsymbol{\xi} \in \mathcal{N}$ と問題 $P_{0}^{\prime}$ は等価である。ここで、

$$
V=V(\underline{\boldsymbol{x}}, \overline{\boldsymbol{x}}, \underline{u}, \overline{\boldsymbol{u}})=V^{I}(\underline{\boldsymbol{x}}, \overline{\boldsymbol{x}}) \cap V^{I I}(\underline{\boldsymbol{x}}, \overline{\boldsymbol{x}}, \underline{u}, \overline{\boldsymbol{u}}) \cap V^{I I I}(\underline{\boldsymbol{x}}, \overline{\boldsymbol{x}})
$$

とする。しかし、問題 $P_{0}^{\prime \prime}$ から非凸制約 $\boldsymbol{\xi} \in \mathcal{N}$ を取り除いて作られ る線形緩和問題

$$
\left(P_{L}^{\prime \prime}\right): \min _{\xi}[f(\boldsymbol{x})]_{l}, \quad \text { s.t. } \boldsymbol{\xi} \in[\Omega]_{l}, \underline{\boldsymbol{\xi}} \leq \boldsymbol{\xi} \leq \overline{\boldsymbol{\xi}}, \boldsymbol{\xi} \in[V]_{l}
$$

と $P_{L}^{\prime}$ は等価ではなく、 $P_{L}^{\prime \prime}$ でなされた緩和は $P_{L}^{\prime}$ の緩和よりも強い ものである。整理すると、各問題の許容領域に対応する集合

$$
\begin{aligned}
& \left(P_{0}^{\prime}\right) \mathcal{F}_{0}^{\prime}=\left\{\boldsymbol{\xi} \mid \boldsymbol{\xi} \in[\Omega]_{l}, \underline{\boldsymbol{\xi}} \leq \boldsymbol{\xi} \leq \overline{\boldsymbol{\xi}}, \boldsymbol{\xi} \in \mathcal{N}\right\}, \\
& \left(P_{L}^{\prime}\right) \mathcal{F}_{L}^{\prime}=\left\{\boldsymbol{\xi} \mid \boldsymbol{\xi} \in[\Omega]_{l}, \underline{\boldsymbol{\xi}} \leq \boldsymbol{\xi} \leq \overline{\boldsymbol{\xi}}\right\}, \\
& \left(P_{0}^{\prime \prime}\right) \mathcal{F}_{0}^{\prime \prime}=\left\{\boldsymbol{\xi} \mid \boldsymbol{\xi} \in[\Omega]_{l}, \underline{\boldsymbol{\xi}} \leq \boldsymbol{\xi} \leq \overline{\boldsymbol{\xi}}, \boldsymbol{\xi} \in[V]_{l}, \boldsymbol{\xi} \in \mathcal{N}\right\}, \\
& \left(P_{L}^{\prime \prime}\right) \mathcal{F}_{L}^{\prime \prime}=\left\{\boldsymbol{\xi} \mid \boldsymbol{\xi} \in[\Omega]_{l}, \underline{\boldsymbol{\xi}} \leq \boldsymbol{\xi} \leq \overline{\boldsymbol{\xi}}, \boldsymbol{\xi} \in[V]_{l}\right\},
\end{aligned}
$$

は包含関係 $\mathcal{F}_{0}^{\prime}=\mathcal{F}_{0}^{\prime \prime} \subset \mathcal{F}_{L}^{\prime \prime} \subset \mathcal{F}_{L}^{\prime}$ を満たす。問題 $P_{0}$ と問題 $P_{0}^{\prime}$ は等 価であったので、妥当不等式によって問題 $P_{L}^{\prime}$ より “強い” 線形緩 和問題 $P_{L}^{\prime \prime}$ が得られることがわかる。

\section{4 上下限制約の領域縮小}

許容領域 $\mathcal{F}_{L}^{\prime \prime}$ は $\underline{\boldsymbol{\xi}}, \overline{\boldsymbol{\xi}}$ に依存するので $\mathcal{F}_{L}^{\prime \prime}(\underline{\boldsymbol{\xi}}, \overline{\boldsymbol{\xi}})$ と表す。線形緩和 問題 $P_{L}^{\prime \prime}$ における緩和効果と設計变数の上下限值 $\underline{\boldsymbol{\xi}}, \overline{\boldsymbol{\xi}}$ の大きさと の間には密接な関係がある16)。より強い緩和問題を得るためには、 元問題 $P_{0}^{\prime \prime}$ の許容領域 $\mathcal{F}_{0}^{\prime \prime}$ を削ることなく、かつ $\underline{\boldsymbol{\xi}} \leq \boldsymbol{\xi} \leq \overline{\boldsymbol{\xi}}$ により作

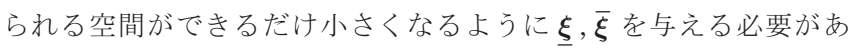
る。すなわち、更新前の上下限值 $\boldsymbol{\xi}, \overline{\boldsymbol{\xi}}$ 打よび更新後の上下限值 $\underline{\boldsymbol{\xi}}^{\prime}, \overline{\boldsymbol{\xi}}^{\prime}$ に対して、 $\mathcal{F}_{0}^{\prime \prime} \subset \mathcal{F}_{L}^{\prime \prime}\left(\underline{\boldsymbol{\xi}}^{\prime}, \overline{\boldsymbol{\xi}}^{\prime}\right) \subset \mathcal{F}_{L}^{\prime \prime}(\underline{\boldsymbol{\xi}}, \overline{\boldsymbol{\xi}})$ かつ $\underline{\boldsymbol{\xi}} \leq \underline{\boldsymbol{\xi}}^{\prime} \leq \overline{\boldsymbol{\xi}}^{\prime} \leq \overline{\boldsymbol{\xi}}$ を 満たすように $\underline{\xi}^{\prime} ， \overline{\boldsymbol{\xi}}^{\prime}$ を与える必要がある。そのために文献16, 17)の 考え方を基にして、成分ごとの逐次的な領域縮小を行う。

$\underline{\boldsymbol{\xi}}, \overline{\boldsymbol{\xi}}$ が与えられた下で $\boldsymbol{\xi}$ の第 $m$ 成分に関寸る更新を考える。領 域 $\mathcal{F}_{L}^{\prime \prime}$ 内で $\xi_{m}$ を最小化あるいは最大化する線形計画問題を解き、

$$
\xi_{m}^{\mathrm{MIN}}=\min \left\{\xi_{m} \mid \boldsymbol{\xi} \in \mathcal{F}_{L}^{\prime \prime}\right\}, \quad \xi_{m}^{\mathrm{MAX}}=\max \left\{\xi_{m} \mid \boldsymbol{\xi} \in \mathcal{F}_{L}^{\prime \prime}\right\}
$$


と表す。上下限值 $\underline{\boldsymbol{\xi}}, \overline{\boldsymbol{\xi}}$ の第 $m$ 成分のみを $\xi_{m}^{\mathrm{MIN}}, \xi_{m}^{\mathrm{MAX}}$ に置き換えた もの（すなわち $\left.\underline{\xi}_{m} \leftarrow \xi_{m}^{\mathrm{MIN}}, \bar{\xi}_{m} \leftarrow \xi_{m}^{\mathrm{MAX}}\right)$ に対して

$$
\begin{aligned}
& \underline{\boldsymbol{x}}^{R}=\left(\underline{x}_{1}^{R}, \cdots, x_{n_{X}}^{R}\right)^{T}, \overline{\boldsymbol{x}}^{R}=\left(\bar{x}_{1}^{R}, \cdots, \bar{x}_{n_{X}}^{R}\right)^{T}, \\
& \underline{\boldsymbol{u}}^{\mathrm{R}}=\left(\underline{u}_{1}^{\mathrm{R}}, \cdots, \underline{n}_{n_{U}}^{\mathrm{R}}\right)^{T}, \quad \overline{\boldsymbol{u}}^{\mathrm{R}}=\left(\bar{u}_{1}^{\mathrm{R}}, \cdots, \bar{u}_{n_{U}}^{\mathrm{R}}\right)^{T},
\end{aligned}
$$

を計算する。ここで、

$\underline{x}_{i}^{R}=\max \left\{\left(\underline{y}_{i}^{(k)}\right)^{\frac{1}{k}}, \min \left\{\left(\underline{z}_{i, j}^{(k)} / \bar{u}_{j}\right)^{\frac{1}{k}},\left(\bar{z}_{i, j}^{(k)} / \underline{u}_{j}\right)^{\frac{1}{k}}\right\} ; j \in \mathcal{K}(i), k=1,2,3,4\right\}$,

$\bar{x}_{i}^{R}=\min \left\{\left(\bar{y}_{i}^{(k)}\right)^{\frac{1}{k}}, \max \left\{\left(\underline{z}_{i, j}^{(k)} / \bar{u}_{j}\right)^{\frac{1}{k}},\left(\bar{z}_{i, j}^{(k)} / \underline{u}_{j}\right)^{\frac{1}{k}}\right\} ; j \in \mathcal{K}(i), k=1,2,3,4\right\}$,

$\underline{u}_{j}^{R}=\max \left\{\underline{u}_{j}, \min \left\{\underline{z}_{i, j}^{(k)} /\left(\bar{x}_{j}\right)^{k}, \underline{z}_{i, j}^{(k)} /\left(\underline{x}_{j}\right)^{k}\right\} ; i \in \mathcal{K}(j), k=1,2,3,4\right\}$,

$\bar{u}_{j}^{R}=\min \left\{\bar{u}_{j}, \max \left\{\bar{z}_{i, j}^{(k)} /\left(\underline{x}_{j}\right)^{k}, \bar{z}_{i, j}^{(k)} /\left(\bar{x}_{j}\right)^{k}\right\} ; i \in \mathcal{K}(j), k=1,2,3,4\right\}$,

とする。 $\underline{x}^{R}, \overline{\boldsymbol{x}}^{R}, \underline{\boldsymbol{u}}^{R}, \overline{\boldsymbol{u}}^{R}$ に対して(21)の操作を行い得られるものを

$$
\underline{\boldsymbol{\xi}}^{R}=\underline{\boldsymbol{\xi}}\left(\underline{\boldsymbol{x}}^{R}, \overline{\boldsymbol{x}}^{R}, \underline{\boldsymbol{u}}^{R}, \overline{\boldsymbol{u}}^{R}\right), \overline{\boldsymbol{\xi}}^{R}=\overline{\boldsymbol{\xi}}\left(\underline{\boldsymbol{x}}^{R}, \overline{\boldsymbol{x}}^{R}, \underline{\boldsymbol{u}}^{R}, \overline{\boldsymbol{u}}^{R}\right),
$$

と表す。 $\underline{\boldsymbol{\xi}}^{R}, \overline{\boldsymbol{\xi}}^{R}$ は $\mathcal{F}_{0}^{\prime \prime} \subset \mathcal{F}_{L}^{\prime \prime}\left(\underline{\boldsymbol{\xi}}^{R}, \overline{\boldsymbol{\xi}}^{R}\right) \subset \mathcal{F}_{L}^{\prime \prime}(\underline{\boldsymbol{\xi}}, \overline{\boldsymbol{\xi}})$ および $\underline{\boldsymbol{\xi}} \leq \underline{\boldsymbol{\xi}}^{R} \leq \overline{\boldsymbol{\xi}}^{R}$ $\leq \overline{\boldsymbol{\xi}}$ を満たす。以上の操作は第 $m$ 成分の更新に対応するものであっ たので、 $\underline{\boldsymbol{\xi}}^{R(m)}, \overline{\boldsymbol{\xi}}^{R(m)}$ と表す。このような操作を繰り返すことで緩和 解の精度を向上できる。本研究では、ランダムに順番を決めて $m$ に ついて更新するという単純な方法を採用する。その方法をアルゴリ ズム 2.1 に示す。

アルゴリズム 2.1 においては計 $2|\mathcal{S}|$ の線形計画問題を解く必要 があり、これを複数回繰り返すことも有効である。緩和問題 $P_{L}{ }^{\prime \prime}$ を 解く際に、前処理としてこのような上下限制約の領域縮小を行う。

\section{5 超直方体分割法を用いた分枝限定法}

より良い緩和解を得るため、前節で述べた領域縮小に併せて、超 直方体分割による分枝限定法の適用を考える。超直方体分割とは、 ある一つの設計変数に対し、許容領域を二分割して二つの子問題に 分ける方法である。どの変数をどのように分割するかに方法の効率 は大きく影響を受ける。本研究では、緩和問題を実際に解いて最も 下界を大きく寸るように逐次選択を行うアプローチを採用する。本 節では、緩和問題 $P_{L}^{\prime \prime}$ の許容領域 $\mathcal{F}_{L}^{\prime \prime}$ の $\underline{x}, \bar{x}, \underline{u}, \bar{u} \frown の$ 依存関係を明 示して

$$
\begin{aligned}
\mathcal{F}_{L}^{\prime \prime} & (\underline{x}, \overline{\boldsymbol{x}}, \underline{\boldsymbol{u}}, \overline{\boldsymbol{u}}) \\
\quad & =\left\{\boldsymbol{\xi} \mid \boldsymbol{\xi} \in[\Omega]_{l}, \underline{\boldsymbol{\xi}}(\underline{\boldsymbol{x}}, \overline{\boldsymbol{x}}, \underline{\boldsymbol{u}}, \overline{\boldsymbol{u}}) \leq \boldsymbol{\xi} \leq \overline{\boldsymbol{\xi}}(\underline{x}, \overline{\boldsymbol{x}}, \underline{\boldsymbol{u}}, \overline{\boldsymbol{u}}), \boldsymbol{\xi} \in[V(\underline{\boldsymbol{x}}, \overline{\boldsymbol{x}}, \underline{u}, \bar{u})]_{l}\right\}
\end{aligned}
$$

と表記する。親問題 $P_{L}^{(M)}\left(M \in \mathbb{N}_{0}\right)$ を分割前の緩和問題 $P_{L}^{\prime \prime}$ とする。 問題 $P_{L}^{(M)}$ における上下限值 $\underline{x}, \overline{\boldsymbol{x}}, \underline{\boldsymbol{u}}, \overline{\boldsymbol{u}}$ は問題番号 $M$ に依存し、この 依存関係を明示して $\underline{\boldsymbol{x}}^{(M)}, \overline{\boldsymbol{x}}^{(M)}, \underline{\boldsymbol{u}}^{(M)}, \overline{\boldsymbol{u}}^{(M)}$ と表せば、 $P_{L}^{(M)}$ は

$$
\left(P_{L}^{(M)}\right): \min _{\boldsymbol{\xi}}[f(\boldsymbol{x})]_{l}, \quad \text { s.t. } \boldsymbol{\xi} \in \mathcal{F}_{L}^{\prime \prime}\left(\underline{\boldsymbol{x}}^{(M)}, \overline{\boldsymbol{x}}^{(M)}, \underline{\boldsymbol{u}}^{(M)}, \overline{\boldsymbol{u}}^{(M)}\right)
$$

と表せる。また $M=0$ に対応する $\underline{x}^{(0)}, \overline{\boldsymbol{x}}^{(0)}, \underline{\boldsymbol{u}}^{(0)}, \overline{\boldsymbol{u}}^{(0)}$ は元問題 $P_{0}$ に おける $\underline{x}, \bar{x}, \underline{u}, \bar{u}$ に一致させるとする。さらに以降では、表記を簡 潔にするために $\underline{\boldsymbol{x}}^{(M)}, \overline{\boldsymbol{x}}^{(M)}, \underline{\boldsymbol{u}}^{(M)}, \overline{\boldsymbol{u}}^{(M)}$ も単に $\underline{\boldsymbol{x}}, \overline{\boldsymbol{x}}, \underline{\boldsymbol{u}}, \overline{\boldsymbol{u}}$ と表すが、 これらは元問題 $P_{0}$ のものと一致するとは限らないことに注意され たい。このとき、領域 $\underline{x} \leq \boldsymbol{x} \leq \overline{\boldsymbol{x}}$ について、 $x_{m}=t$ で二つの領域 $\underline{\boldsymbol{x}} \leq \boldsymbol{x} \leq \overline{\boldsymbol{x}}^{B(m, t)}, \underline{\boldsymbol{x}}^{B(m, t)} \leq \boldsymbol{x} \leq \overline{\boldsymbol{x}}$ に分割することを考える。すなわち、 $\underline{\boldsymbol{x}}^{B}(m, t), \overline{\boldsymbol{x}}^{B}(m, t) \in \mathbb{R}^{n_{X}}$ の第 $i$ 成分 $\underline{x}_{i}^{B}(m, t), \bar{x}_{i}^{B}(m, t) ; i=1, \cdots, n_{X}$ を

$$
\underline{x}_{i}^{B}(m, t)=\left\{\begin{array}{cc}
\underline{x}_{i} & (i \neq m) \\
t & (i=m)
\end{array}, \quad \bar{x}_{i}^{B}(m, t)=\left\{\begin{array}{cc}
\bar{x}_{i} & (i \neq m) \\
t & (i=m)
\end{array},\right.\right.
$$

と与える。このような分割に対して、 $N>M$ として二つの子問題

$$
\begin{aligned}
& \left(P_{L}^{(N)}\right): \quad \min _{\xi}[f(\boldsymbol{x})]_{l}, \quad \text { s.t. } \boldsymbol{\xi} \in \mathcal{F}_{L}^{\prime \prime}\left(\underline{\boldsymbol{x}}, \overline{\boldsymbol{x}}^{B}(m, t), \underline{\boldsymbol{u}}, \overline{\boldsymbol{u}}\right), \\
& \left(P_{L}^{(N+1)}\right): \min _{\boldsymbol{\xi}}[f(\boldsymbol{x})]_{l} \text {, s.t. } \boldsymbol{\xi} \in \mathcal{F}_{L}^{\prime \prime}\left(\underline{\boldsymbol{x}}^{B}(m, t), \overline{\boldsymbol{x}}, \underline{\boldsymbol{u}}, \overline{\boldsymbol{u}}\right),
\end{aligned}
$$

\section{アルゴリズム 2.1 (領域縮小)}

ステップ1（更新対象の決定）： $\boldsymbol{\xi}$ から適当に更新対象となる成分 を選び、選ばれた成分に対応寸る番号の集合 $\mathcal{S} \subset\{1,2 \cdots, n\}$ を与え る。ここで、 $n$ は $\boldsymbol{\xi}$ の次元である。

ステップ2（1成分の範囲縮小）: ランダムに $m \in \mathcal{S}$ を選び、 $(27)$ よ り $\xi_{m}^{\mathrm{MIN}}, \xi_{m}^{\mathrm{MAX}}$ を計算する。

ステップ3 (領域縮小) : 上下限值 $\underline{\boldsymbol{\xi}}, \overline{\boldsymbol{\xi}}$ の第 $m$ 成分のみを $\xi_{m}^{\mathrm{MIN}}, \xi_{m}^{\mathrm{MAX}}$ に置き換えたものに対して(28),(29)から $\boldsymbol{\xi}^{R(m)}, \boldsymbol{\xi}^{R(m)}$ を計算する。 上下限值を $\underline{\boldsymbol{\xi}} \leftarrow \underline{\boldsymbol{\xi}}^{R(m)}, \overline{\boldsymbol{\xi}} \leftarrow \overline{\boldsymbol{\xi}}^{R(m)}$ と更新する。

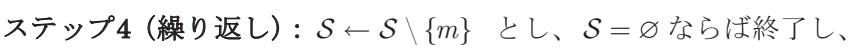

そうでなければステップ 2 に戻る。

アルゴリズム 2.2（超直方体分割を用いた分枝限定法）

ステップ0 (パラメータ設定) : 問題数の上限值 $\bar{N}>0$ 、上界と下界 の許容ギャップ をを与える。

ステップ1 (上界の計算) : 元問題 $P_{0}$ を非線形最適化ソルバーで解き、 得られた局所解に対する目的関数值 $f^{*}$ を上界值 $\bar{f} \leftarrow f^{*}$ とする。

ステップ2 (下界の初期值) : 問題集合 $\mathcal{P}=\varnothing を$ を定義する。線形緩和 問題 $P_{L}^{(0)}$ に対しアルゴリズム2.1を適用して領域縮小を行う。領域 縮小された問題 $P_{L}^{(0)}$ を解き、その最適值 $\hat{f}$ を界值 $f \leftarrow \hat{f}$ とする。 さらに線形緩和問題 $P_{L}^{(0)}$ を問題集合 $\mathcal{P}$ に加える。

ステップ3(親問題選択)：P の中で、最適值が一番低い問題 $P_{L}^{(M)}\left(M \in \mathbb{N}_{0}\right)$ を選び、P $\mathcal{P} ら$ 取り除く。

ステップ4（成分番号選択）: 問題 $P_{L}^{(M)}\left(M \in \mathbb{N}_{0}\right)$ の最適解（緩和解） に対して(34),(32)の操作を行い、分枝対象とする成分番号 $\hat{m}$ を選 択する。

ステップ5 (分割位置選択) : ステップ4で選択された $\hat{m}$ について(35) の操作を行い、分割位置 $\hat{t}$ を選択する。

ステップ6 (分枝操作) : ステップ4,5で選択された成分番号 $\hat{m}$ およ び分割位置 $\hat{t}$ に対して、問題 $P_{L}^{(M)}$ の許容領域を $x_{\hat{m}}=\hat{t}$ で二分割す る。(31)に示されるような二つの子問題 $P_{L}^{(N)}, P_{L}^{(N+1)}$ が得られる。 それぞれにアルゴリズム $2.1 を$ 繰り返し適用して領域縮小を行っ てから $P_{L}^{(N)}, P_{L}^{(N+1)}$ を解き、 $N \leftarrow N+2$ と寸る。許容解が得られた 子問題を $\mathcal{P}$ に加え、許容な子問題において最も低い最適值を $\hat{f}$ と する。 $\hat{f}>\underline{f}$ の場合、 $\underline{f} \leftarrow \hat{f}$ と更新する。

ステップ7 (終了判定) : $N$ が設定した值 $\bar{N}$ を超えた場合、あるい は緩和ギャップ $\bar{f}-\underline{f} \leq \varepsilon$ の場合、 $\underline{f}$ を下界值として出力して終了 する。そうでなければステップ3に戻る。

を定義する。（31）における成分番号 $m$ および分割位置 $t$ の決定方法 を以下に説明する。

親問題 $P_{L}^{(M)}$ の最適解（緩和解）を $\hat{\boldsymbol{\xi}}=\left(\hat{\boldsymbol{y}}^{T}, \hat{\boldsymbol{u}}^{T}, \hat{\boldsymbol{z}}^{T}\right)^{T}$ とする。緩和 解の精度を向上させるためには緩和解付近で分割することが望まし い。(19)で定義したように $x_{i}$ に $y_{i}^{(1)}$ を対応させたので、分割後に最 も下界を上昇させるような最適成分番号 $\hat{m}$ を次式から求める。

$$
\hat{m}=\underset{i \in\left\{1,2, \cdots, n_{X}\right\}}{\arg \max }\left\{\underline{f}_{N}^{B \min }(m, t) \mid m=i, t=\hat{y}_{i}^{(1)}\right\}
$$

ここで、

$$
\begin{aligned}
& \underline{f}_{N}^{B}(m, t)=\min _{\boldsymbol{\xi}}\left\{[f(\boldsymbol{x})]_{l} \mid \boldsymbol{\xi} \in \mathcal{F}_{L}^{\prime \prime}\left(\underline{\boldsymbol{x}}, \overline{\boldsymbol{x}}^{B}(m, t), \underline{\boldsymbol{u}}, \overline{\boldsymbol{u}}\right)\right\}, \\
& \underline{f}_{N+1}^{B}(m, t)=\min _{\boldsymbol{\xi}}\left\{[f(\boldsymbol{x})]_{l} \mid \boldsymbol{\xi} \in \mathcal{F}_{L}^{\prime \prime}\left(\underline{\boldsymbol{x}}^{B}(m, t), \underline{\boldsymbol{x}}, \underline{\boldsymbol{u}}, \overline{\boldsymbol{u}}\right)\right\},
\end{aligned}
$$




$$
\underline{f}_{N}^{B \min }(m, t)=\min \left\{\underline{f}_{N}^{B}(m, t), \underline{f}_{N+1}^{B}(m, t)\right\}
$$

とする。なお、(32)を解くためには $2 n_{X}$ 個の線形計画問題を解く必 要がある。最適成分番号 $\hat{m}$ を決定した後に、最適分割位置の計算を 行う。非凸制約 $\boldsymbol{\xi} \in \mathcal{N}$ を満たせば

$$
\begin{aligned}
x_{i} & =y_{i}^{(1)}=\left(y_{i}^{(2)}\right)^{1 / 2}=\left(y_{i}^{(3)}\right)^{1 / 3}=\left(y_{i}^{(4)}\right)^{1 / 4} \\
& =z_{i, j}^{(1)} / u_{j}=\left(z_{i, j}^{(2)} / u_{j}\right)^{1 / 2}=\left(z_{i, j}^{(3)} / u_{j}\right)^{1 / 3}=\left(z_{i, j}^{(3)} / u_{j}\right)^{1 / 3} ; j \in \mathcal{K}(i)
\end{aligned}
$$

が成立するが、緩和解 $\hat{\boldsymbol{\xi}}$ においてこの関係が成立しているとは限ら ない。そこで、 $\hat{x}$ ๙の逆写像が存在する上限

$$
\bar{y}_{i}^{(1)}=\max \left\{\left(\hat{y}_{i}^{(k)}\right)^{1 / k},\left(\hat{z}_{i, j}^{(k)} / \hat{u}_{j}\right)^{1 / k} ; k=1,2,3,4, j \in \mathcal{K}(i)\right\}
$$

を与えて、最適分割位置の計算を次式から行う。

$$
\hat{t}=\underset{\hat{i}_{i}^{(1)} \leq t \leq \bar{y}_{i}^{(1)}}{\arg \max }\left\{f_{N}^{B \min }(\hat{m}, t)\right\}
$$

(35)は1変数最適化問題であるが、(33)を評価するために線形緩和問 題を繰り返し解く必要がある。次章の数值解析例では指定回数を 10 回以内と与えた黄金分割法18)を用いて最適分割位置 $\hat{t}$ 求めた。こ のような分枝限定法をアルゴリズム 2.2 に示す。

アルゴリズム 2.2 においては多数の緩和問題を解く必要がある。た だし、これらの緩和問題は線形計画問題であるので、数值的に安定 かつ高速な線形計画ソルバーを利用可能である。

\section{3 数值解析例}

\subsection{3層3スパンモデル解析例}

図7に示す 3 層 3 スパン鋼構造純ラーメン骨組モデルの例題を考え る。す心゙ての部材でSN490級鋼を用い、柱部材には角形鋼管、梁 部材にはH形鋼を用いる。床荷重の幅を6.4メートルとし、床荷重 として基準階 $7.75 \mathrm{kN} / \mathrm{m}^{2} 、 \mathrm{R}$ 階 $10.09 \mathrm{kN} / \mathrm{m}^{2}$ を与え、図7に示すよう に基準階、R階にそれぞれ一様分布荷重を $49.6 \mathrm{kN} / \mathrm{m}, 64.6 \mathrm{kN} / \mathrm{m}$ と 与える。さらに $\mathrm{Ai}$ 分布 $\left(\mathrm{C}_{0}=0.2\right)$ に従った水平荷重を図7に示寸よう に与える。本論文では仮定 $1,2,3$ ので 1 次短期設計のみを考え、 1 次短期設計用荷重時には鉛直荷重と水平荷重を同時に作用させ、許 容最大層間変形角として全層1/200以下、短期許容応力度として $325 \mathrm{~N} / \mathrm{mm}^{2}$ をえる。

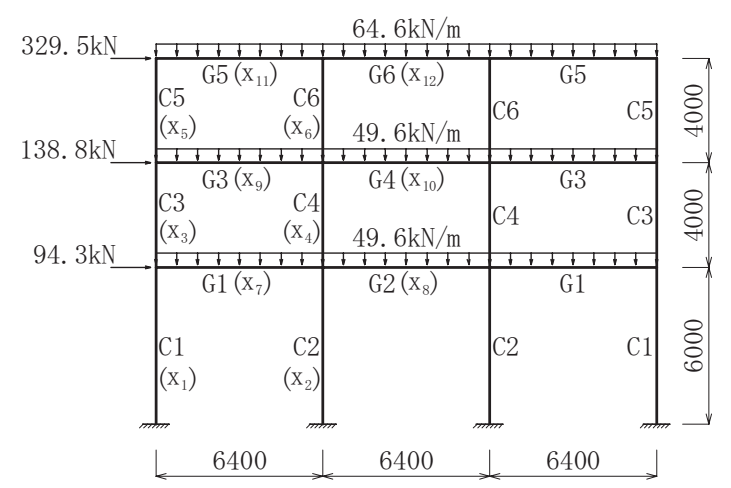

図7 3層3スパンモデル

部材断面の設計変数は図7に示す断面番号に対応するように与え、 さらに対応する設計変数の上下限值を次のように与える。

$$
\left\{\begin{array}{lll}
10 \leq x_{i} \leq 40 ; & i=1,2, \cdots, 6, & \text { (柱部材断面) } \\
10 \leq x_{i} \leq 20 ; & i=7,8, \cdots, 12 & \text { (梁部材断面) }
\end{array}\right.
$$

上界として適当な許容解を求めるために、非線形最適化法である有 効制約法 ${ }^{199)}$ により元問題 $P_{0}$ を解く。設計変数の初期值としては(36) における上限值を与えた。以上より求められた上界（局所解の目的 関数値）は $\bar{f}=1.602 \mathrm{~m}^{3}$ であった。この設計解の断面積分布を線の 太さに比例させて描いたものを図8に示す。

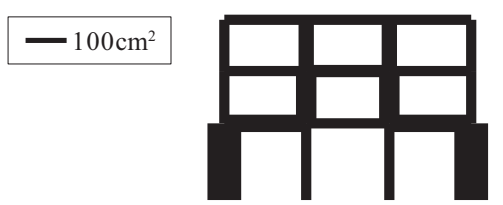

図8 上界に対応寸る）局所解の断面積分布

次に変位の上下限值を設定するために、変位の各成分について

$$
\begin{aligned}
& \underline{u}_{i}:=\min _{\boldsymbol{x}, u}\left\{u_{i} \mid \boldsymbol{K}(\boldsymbol{x}) \boldsymbol{u}=\boldsymbol{P}, \boldsymbol{R} \boldsymbol{u} \leq \overline{\boldsymbol{\delta}}, \boldsymbol{s}(\boldsymbol{x}, \boldsymbol{u})\right. \leq \mathbf{0}, \\
&\underline{\boldsymbol{x}} \leq \boldsymbol{x} \leq \overline{\boldsymbol{x}}, f(\boldsymbol{x}) \leq 1.05 \bar{f}\}, \\
& \bar{u}_{i}:=\max _{\boldsymbol{x}, \boldsymbol{u}}\left\{u_{i} \mid \boldsymbol{K}(\boldsymbol{x}) \boldsymbol{u}=\boldsymbol{P}, \boldsymbol{R} \boldsymbol{u} \leq \overline{\boldsymbol{\delta}}, \boldsymbol{s}(\boldsymbol{x}, \boldsymbol{u}) \leq \mathbf{0},\right. \\
&\underline{\boldsymbol{x}} \leq \boldsymbol{x} \leq \overline{\boldsymbol{x}}, f(\boldsymbol{x}) \leq 1.05 \bar{f}\},
\end{aligned}
$$

を求める。ここでも有効制約法を用い、上界に対応する設計解を初 期值として与える。以上に対し、問題数の上限值 $\bar{N}=300$ 、許容ギ ヤップ $\varepsilon=0$ を与え、アルゴリズム 2.2 を適用する。実行環境は

CPU : Intel Core i7 2600K 3.4GHz, OS: Windows 7 ,

$$
\text { MATLAB R2011a }{ }^{18)} \text {, CPLEX 12.20) }
$$

である。この解析例において、一回の分枝すなわちアルゴリズム 2.2 におけるステップ3からステップ6を一度行うには平均 76 秒を要し た。なお、一回の分枝では多数の線形計画問題を解いた結果として 二つの子問題の最適值が得られる。上下界の目的関数の乘離度を $(\bar{f}-\underline{f}) / \bar{f}$ と定義し、子問題を解く回数と乘離度との関係を表 $2 お$ よび図9に示す。表 2 に示すように、300の子問題を解き終わった段 階での乘離度は $2.59 \%$ あったたこれは図 9 に示した設計解から目的 関数值を $2.59 \%$ 以上は減らすことができないことを意味する。

表2 子問題数と乘離度の関係（3層3スパンモデル）

\begin{tabular}{c|ccc}
\hline 子問題数 & $\begin{array}{c}\text { 下界值 } \underline{f} \\
\left(\mathrm{~m}^{3}\right)\end{array}$ & $\begin{array}{c}\text { 上界值 } \bar{f} \\
\left(\mathrm{~m}^{3}\right)\end{array}$ & $\begin{array}{c}\text { 乘離度 } \\
(\bar{f}-\underline{f}) / \bar{f}\end{array}$ \\
\hline \hline 0 & 1.372 & 1.602 & $14.34 \%$ \\
50 & 1.514 & 1.602 & $5.43 \%$ \\
100 & 1.538 & 1.602 & $3.97 \%$ \\
300 & 1.554 & 1.602 & $2.97 \%$ \\
\hline
\end{tabular}

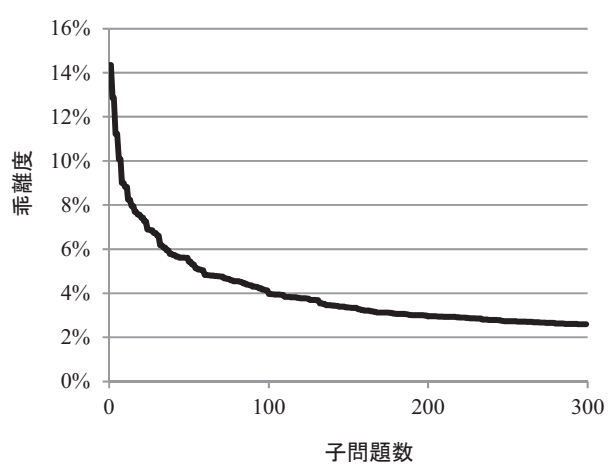

図9 子問題数と乘離度の関係 (3層3スパンモデル) 
$2.59 \%$ 以下であればさらに小さい目的関数值を持つ設計解が存在す る可能性はある。このことを確認するために、300の子問題を解き 終わった段階でのアルゴリズム 2.2 における問題集合 $\mathcal{P}$ に含まれる 分割領域、寸なわち現在の局所解よりも良い設計解が存在する可能 性が残る領域の全てについて、非凸制約(20)を考慮して有効制約法 を用いて解き直した。これは、多点探索による非線形最適化を行っ て上界值を更新したとも解釈できる。以上により新たに発見された 設計解のうち代表的なものについて、図8 8 同じ縮尺で線の太さに 比例させた断面積分布を図10に示寸。また、これらの設計解の目的 関数值、最初に設定した上界、および300の子問題を解き終わった 段階での下界を併せて表3に示す。

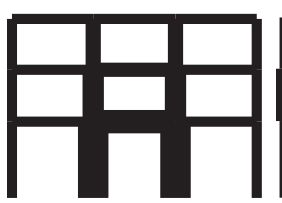

(a) 設計解1

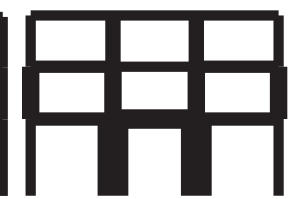

(b) 設計解 2

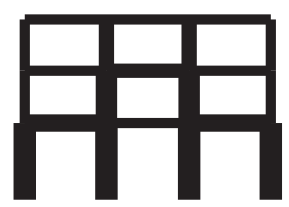

(c) 設計解3
図10 新たに発見された設計解の断面積分布

表3 新たに発見された局所解の目的関数值

\begin{tabular}{c|ccccc}
\hline & 上界 & 下界 & 設計解1 & 設計解 2 & 設計解3 \\
\hline \hline 目的関数值 $\left(\mathrm{m}^{3}\right)$ & 1.602 & 1.560 & 1.569 & 1.606 & 1.633 \\
\hline
\end{tabular}

最初に設定した上界よりもさらに小さな目的関数值を持つ設計解が 存在することが表 3 より確認され、そのような最良の設計解である 設計解 1 目的関数值と下界との乘離度は $0.58 \%$ でった。さらに小 さな目的関数值を持つ設計解が存在する可能性はあるものの、その ような設計解と設計解 1 との目的関数值の差は $0.58 \%$ 以内に必ず収 まることが保証される。必要であれば分枝操作をさらに続けること によりその精度をより高めることも可能である。

図8に示した局所解は下層の柱が上層の柱よりも小さい、所謂チ ェッカーボード状の断面積分布である。一方、最良の設計解である 図10における設計解1は中央の柱部材が大きい、言わば中央コアを 配置した断面積分布に近い。チェッカーボード状の断面積分布が非 線形最適化法により最適解として得られることが多いが、信頼性の 不確かな局所解のみから問題の定性的な傾向を把握寸る結論付ける ことは難しい。よって、本研究で示すような方法の有用性が例示さ れたと言える。

\section{2 7層3スパンモデル解析例}

図11に示すような 7 層3スパン鋼構造純ラーメン骨組モデルの例 題を考える。柱部材には角形鋼管、梁部材にはH形鋼を用い、設計 変数の上下限值を次のように与える。

$$
\left\{\begin{array}{l}
15 \leq x_{i} \leq 40 ; \quad i=1,2, \cdots, 14, \quad （ \text { 柱部材断面） } \\
10 \leq x_{i} \leq 20 ; \quad i=15,16, \cdots, 12 （ \text { 梁部材断面） }
\end{array}\right.
$$

床荷重の幅を6.4メートルとし、図11に示すような鉛直荷重および水 平荷重を与える。その他については前節で述べた 3 層3スパンモデル 解析例と同様に設定する。

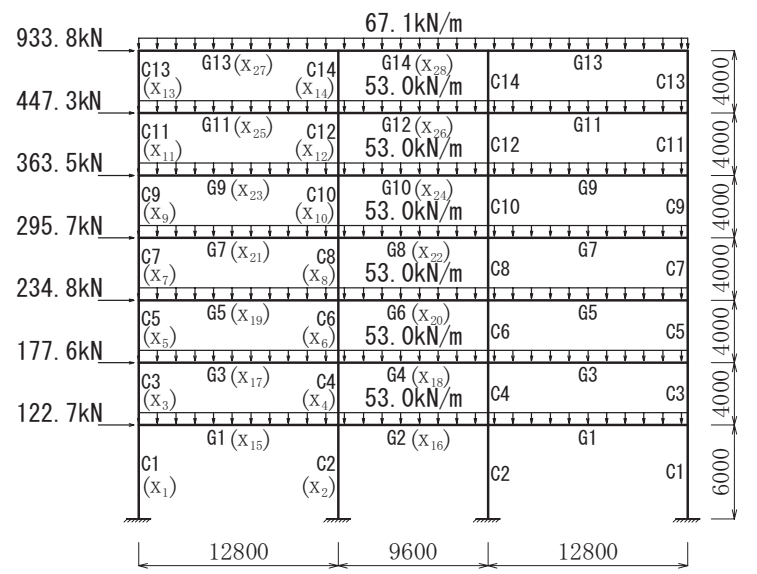

図11７層3スパンモデル

有効制約法により得られた目的関数值の上界は $\bar{f}=10.774 \mathrm{~m}^{3}$ で あり、一回の分枝を行うには平均 1,049 秒を要した。子問題を解く 回数と目的関数值の上下界の乘離度との関係を図 12 に示す。

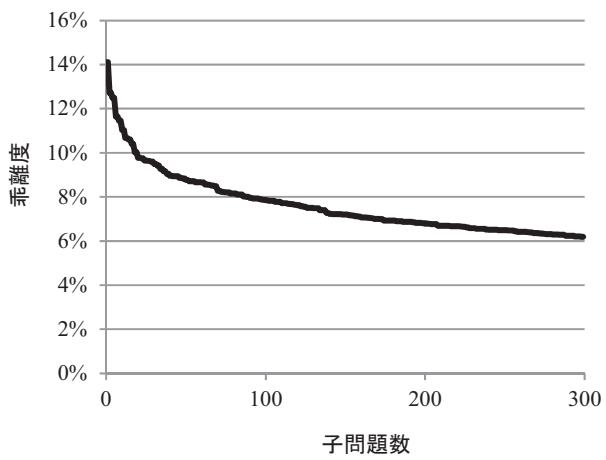

図12 子問題数と乘離度の関係（7層3スパンモデル）

300 の子問題を解き終わった段階での下界と上界との乘離度は $6.19 \%$ であり、モデルの規模が大きくなるにつれて緩和界の精度が 低下していると推察される。ただし、これは解くべき子問題の数を 制限した場合のことであり、子問題の数を無限に増やすことを許せ ば正確な最適值を得られることが理論的には知られている16)。よっ て、問題の規模に関わらず必要とするだけの精度を有する下界を得 ることも理論的には可能である。上界に対応する局所解の断面積分 布を線の太さに比例させたものを図13(a)に、前節と同様に有効制約 法を用いて新たに探索した設計解を図8(b),(c)に示す。また、これら の設計解の目的関数值を表4に示す。

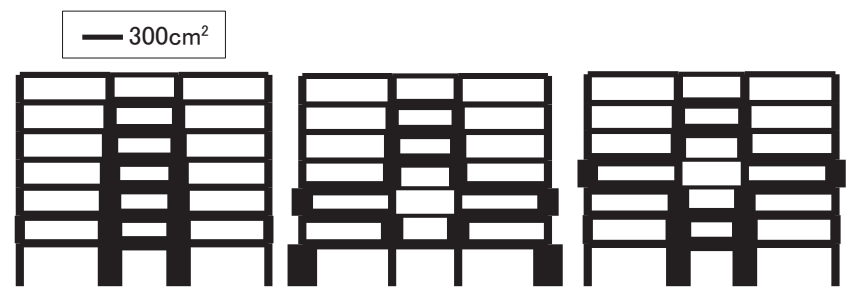

（a）局所解（上界）

(b) 設計解1

(c) 設計解 2

図13 各設計解の断面積分布 
表4 新たに発見された局所解の目的関数值

\begin{tabular}{l|cccc}
\hline & 上界 & 下界 & 設計解1 & 設計解2 \\
\hline \hline 目的関数值 $\left(\mathrm{m}^{3}\right)$ & 10.774 & 10.106 & 11.104 & 11.125 \\
\hline
\end{tabular}

表4に示されるように、この解析例においては最初に設定した上界 よりも良い目的関数值を持つ設計解は発見できなかった。よって、 この場合は最初に設定した上界が良い推定值であったと言える。こ のような上界（局所解）の妥当性の定量的評価は本手法のような凸 緩和方法を用いて初めて可能となるものである。また、この解析例 においてもチェッカーボード状の設計解はコスト増加につながって いる。どのような設計解が有利かはモデル化や設計条件により変わ り、一概には言えないことが予想される。既往のアプローチでは精 度の不確かな局所解しか発見できないので、そのような方法に基づ いて最適解の定性的な考察を行うことは妥当ではない。本方法を用 いれば、ある設計解がどの程度有利であるかを定量的に確認するこ とが可能である。このような縓密な意味での定量的なスタディを重 ねて初めて、ある与えられた条件ではどのような設計が望ましいか の定性的な考察が可能になると考える。

\section{4 まとめ}

本論文で得られた結論は以下の通りである。

(1) 鋼構造平面骨組の鋼材量最小化問題について多項式計画問題の 定式化、およびRLTに基づく線形緩和問題の定式化を示した。 このような定式化により、鋼構造平面骨組における局所解に対 して、どの程度妥当な解であるかを評価することができる。

（2）新たな領域分割の方法に基づく分枝限定法により、緩和問題の 精度を向上する方法を示した。分枝限定法では多数の緩和問題 を解く必要がある。ただし、これらの緩和問題は線形計画問題 であるので、大規模な問題を数值的に安定かつ高速に解くこと ができる線形計画ソルバーを利用可能である。

（3）緩和解（下界）と局所解（上界）を用いて、局所解の信頼性を どの程度評価することが可能かについて、数值解析例を通じて 調ベた。3層3スパンモデル解析例では、大域的最適解との目的 関数值の差が $0.58 \%$ 以内に保証された設計解を得られた。一方、 3層3スパンモデル解析例と同様に解くべき子問題数を 300 に制 限した場合、7層3スパンモデル解析例では上界と下界との乘離 度が $6.19 \%$ であり、規模が大きくなるに従い精度は低下した。

（4）3層3スパンモデル、7層3スパンモデルどちらの解析例において も、チェッカーボード状の設計解はコスト増加につながってい た。どのような設計解が有利かは、モデル化や設計条件により 変わることが予想される。本方法のような縓密な意味での定量 的なスタディを重ねて初めて、このような問題の定性的な考察 が可能になると考える。

\section{謝辞}

本研究の一部は、科研費(No.23360245)、および財団法人鴻池奨 学財団「平成 23 年度助成対象研究」の助成を受けて行われた。ここ に記して謝意を表す。

\section{参考文献}

1) J. S. Arora: Optimaization of Structural and Mechanical Systems, World Scientific, 2007

2) R. T. Haftka, Z. Gürdal: Elements of structural optimization, Springer, 1992

3) M. Ohsaki: Local and global searches of approximate optimal designs of regular frames, International Journal for Numerical Methods in Engineering, Vol.67, No.1, pp.132-147, 2006

4）松本慎也，荒井宏，春日康博，et al：鉄骨骨組構造の最小重量設計におけ る局所解の一例，構造工学論文集, B, Vol.45, pp.249-258, 1999

5）久保幹雄, 田村明久, 松井知已：応用数理計画ハンドブック，朝倉書店, 2002.5

6）澤田樹一郎，松尾彰：弾性・塑性制約下における鋼構造建築骨組の離散最 適化問題に対する列挙型アルゴリズムの改善解法, 日本建築学会構造系論 文集, No.574, pp.93-98, 2003.12

7) NZ Shor: Dual quadratic estimates in polynomial and boolean programming, Annals of Operations Research, Vol.25, No.1, pp.163-168, 1990

8) H. D. Sherali, C. H. Tuncbilek: A global optimization algorithm for polynomial programming problems using a reformulation-linearization technique, Journal of Global Optimization, Vol.2, No.1, pp.101-112, 1992

9) S. Kim, M. Kojima: Second order cone programming relaxation of nonconvex quadratic optimization problems, Optimization Methods and Software, Vol.15, No.3-4, pp.201-224, 2001

10) T. Fujie, M. Kojima: Semidefinite relaxation for nonconvex programs, Journal of Global Optimization, Vol.10, pp.367-380, 1997

11) M. X. Goemans, D. P. Williamson: Improved approximation algorithms for maximum cut and satisfiability problems using semidefinite programming, Journal of the ACM (JACM), Vol.42, No.6, pp.1115-1145, 1995

12) Y. Nesterov: Semidefinite relaxation and nonconvex quadratic optimization, Optimization Methods and Software, Vol.9, No.1/3, pp.141-160, 1998

13) J. B. Lasserre: Semidefinite programming vs. LP relaxations for polynomial programming, Mathematics of Operations Research, pp.347-360, 2002

14) K. M. Anstreicher: Semidefinite programming versus the reformulation-linearization technique for nonconvex quadratically constrained quadratic programming, Journal of Global Optimization, Vol.43, No.2, pp.471-484, 2009

15) Hans Mittelmann: Benchmarks for Optimization Software, http://plato.asu.edu/bench.html, 2011.08.01

16) C. Audet, P. Hansen, B. Jaumard, G. Savard: A branch and cut algorithm for nonconvex quadratically constrained quadratic programming, Mathematical Programming, Vol.87, No.1, pp.131-152, 2000

17) H. D. Sherali, C. H. Tuncbilek: New reformulation linearization /convexification relaxations for univariate and multivariate polynomial programming problems, Operations Research Letters, Vol.21, No.1, pp.1-9, 1997

18) MATLAB Mathematics R2011a, The MathWorks, Inc., Natick, MA, 2011

19) Optimization Toolbox 6.0 User's Guide, The MathWorks, Inc., Natick, MA, 2011

20) IBM ILOG CPLEX V12.2: User's Manual for CPLEX, International Business Machines Corporation, 2010

（2011年 9 月10日原稿受理，2011年12月16日採用決定） 